\title{
MyiMonitor.com v. 1: a user-friendly mobile electronic diary for bipolar patients
}

Yanni Malliaris

From $1^{\text {st }}$ International Congress on Neurobiology and Clinical Psychopharmacology and European

Psychiatric Association Conference on Treatment Guidance

Thessaloniki, Greece. 19-22 November 2009

Subsyndromal symptoms and daily symptom variability is a potential risk factor for bipolar relapse. iMonitor is a mobile palm based electronic diary that was developed to measure this variability and to assist bipolar patients to track the daily course of their illness. iMonitor was designed to measure day to day fluctuations in bipolar symptom states and to track core features of the bipolar illness, such as sleep duration, mood variability, function, activation, self-esteem variability, medication adherence, and life events using visual analogue scales (VAS) following the NIMH-LCM method. In addition, a special feature of iMonitor is its ability to customise itself to each patient's relapse signature and to allow the tracking of more individual signs of relapse. The current version of iMonitor was developed to run on the cheapest possible handheld devices (Palm OS) in order to facilitate the application of electronic monitoring in low income patients who do not have access to personal computers (PCs) and the internet. The design of iMonitor appears relatively simple but this was based on advanced usability principles that serve to ensure an effortless user experience. Preliminary validation data have been gathered in the Maudsley Bipolar eMonitoring Project, and will be briefly discussed.

Published: 22 April 2010

doi:10.1186/1744-859X-9-S1-S12

Cite this article as: Malliaris: MyiMonitor.com v. 1: a user-friendly mobile electronic diary for bipolar patients. Annals of General Psychiatry 2010 9(Suppl 1):S12.

Institute of Psychiatry, King's College London, UK
Submit your next manuscript to BioMed Central and take full advantage of:

- Convenient online submission

- Thorough peer review

- No space constraints or color figure charges

- Immediate publication on acceptance

- Inclusion in PubMed, CAS, Scopus and Google Scholar

- Research which is freely available for redistribution

Submit your manuscript at www.biomedcentral.com/submit
C Biomed Central 